\title{
Single origin of the Mascarene stick insects: ancient radiation on sunken islands?
}

\author{
Sven Bradler ${ }^{{ }^{*}}$ (D), Nicolas Cliquennois ${ }^{2}$ and Thomas R. Buckley $3,4,5$
}

\begin{abstract}
Background: The study of islands as model systems plays a key role in understanding many evolutionary processes. Knowledge of the historical events leading to present-day island communities is pivotal for exploring fundamental mechanisms of speciation and adaptation. The remote Mascarene archipelago (Mauritius, Réunion, Rodrigues), considered to be the product of an age-progressive trend of north-to-south volcanic activity in the Indian Ocean, hosts a remarkably diverse, endemic and threatened concentration of flora and fauna that has traditionally been considered to be biogeographically related to Madagascar and Africa. To explore the evolutionary diversity of the Mascarene stick insects (Phasmatodea), we constructed a global phylogeny from approximately $2.4 \mathrm{~kb}$ of mitochondrial and nuclear sequence data of more than 120 species representing all major phasmatodean lineages.

Results: Based on the obtained time-calibrated molecular tree we demonstrate that the current phasmid community of the Mascarene archipelago, which consists of members of four presumably unrelated traditional subfamilies, is the result of a single ancient dispersal event from Australasia and started radiating between 16-29 million years ago, significantly predating the age of Mauritius (8-10 million years).

Conclusions: We propose that the Mascarene stick insects diversified on landmasses now eroded away, presumably to the north of Mauritius. In consequence, ancient islands have probably persisted in the Indian Ocean until the emergence of Mauritius and not only served as stepping stones for colonisation events during sea-level lowstands, but as long-lasting cradles of evolution. These ancient landmasses most likely allowed for adaptive speciation and served as significant sources of diversity that contributed to the biomes of the Mascarene archipelago and the megadiverse Madagascar.
\end{abstract}

\section{Background}

The Indian Ocean harbours a number of major terrestrial biodiversity hotspots including Madagascar and nearby archipelagos of the Comores, Seychelles and Mascarenes [1]. While Madagascar and the granitic Seychelles are of old continental origins, the Mascarene Islands Mauritius and Réunion have been shown to be much younger as the result of the similar process of plate movement over a stationary volcanic hot spot that formed the Hawaiian archipelago and the Galápagos Islands in the Pacific [2-5]. Recent studies suggest the presence of Precambrian, albeit currently submerged continental fragments underneath the Mascarene Plateau covered by magmatic deposits in

\footnotetext{
* Correspondence: sbradle@gwdg.de

'Johann-Friedrich-Blumenbach-Institute of Zoology and Anthropology, Georg-August-University Göttingen, Berliner Str. 28, 37073 Göttingen, Germany

Full list of author information is available at the end of the article
}

the Indian Ocean that separated from Madagascar about 61-83.5 million years ago (mya) [6]. Although less well-studied, biologically speaking, than the Hawaiian and Galápagos Islands, the Mascarene archipelago appears to be likewise rich in biodiversity, notably in endemics [7]. Unfortunately, the Mascarene Islands, Mauritius and Rodrigues in particular, have already lost a significant amount of this endemic diversity since human settlement in the $17^{\text {th }}$ century due to habitat destruction $[7,8]$. Understanding the biogeographic processes leading to endemic diversity is crucial both to interpretation of their evolutionary history and to the establishment of conservation strategies [9]. The majority of the extant species diversity of the Mascarene Islands has been described as the result of recent colonisations from outside the archipelago and divergence within the contemporary island system, often with immigrating lineages derived from Madagascar and Africa [10-14]. Yet, unexpectedly, 
numerous faunal elements are related to more remote regions such as Asia and the Indo-Pacific [7, 15-18]. In some taxonomic groups like skinks and stick insects, colonisations of the Mascarenes appear to have involved longdistance dispersals from the Australian region ranging between 5600-7000 km [19, 20].

Stick and leaf insects (insect order Phasmatodea) are particularly informative organisms for historical biogeographic research due to their limited dispersal capabilities, manageable species numbers and ease of sampling. Phasmatodeans are predominantly large nocturnal herbivores, exhibiting extreme forms of plant mimicry (Fig. 1), with very limited flight capability. Stick insects must be considered as being non-volant although they often possess wings, which they generally use to control descent from the canopy rather than for sustained flying [21]. The Mascarene islands harbour stick insects from four traditional subfamilies and one taxon incertae sedis $[22,23]$, suggesting repeated transoceanic colonisations of the archipelago by unrelated phasmatodean lineages. However, previous studies demonstrated that geographical distribution rather than traditional classification and morphological similarity reflects the evolutionary relationships among stick and leaf insects [20, 24]. Here we provide another example of an unexpected adaptive radiation of stick insects in geographical isolation and that furthermore, the age of this radiation predates the origin of the islands that these species currently inhabit.

\section{Results}

This study represents the most comprehensive study addressing the global phylogeny of stick and leaf insects to date and the first one to include a representative sampling from landmasses of the Indian Ocean, e.g., from Madagascar and the Mascarene archipelago.
We sampled $\sim 2.4 \mathrm{~kb}$ of nuclear and mitochondrial sequence data from 121 phasmatodean individuals (representing $120 \mathrm{spp}$.) and 1 individual (Metoligotoma) of the outgroup Embioptera (webspinners). The relaxed clock model placed the root on the branch between the Embioptera and Phasmatodea (Fig. 2), consistent with previous insect phylogenies [25-29]. The next split was between Timema and the Euphasmatodea, again consistent with previous phylogenetic reconstructions of the Phasmatodea $[25,30]$. The recovered phylogeny was consistent with current phylogenetic hypotheses on stick and leaf insects including some ambiguities at deeper nodes, e.g., the radiation of major phasmatodean lineages, which are currently poorly resolved [24, 31, 32]. We observed strong support for several monophyletic groups, including Aschiphasmatinae (Maximum likelihood bootstrap [MLB] $=98$, Bayesian posterior probability $[\mathrm{BPP}]=0.99)$, Cladomorphinae $(\mathrm{MLB}=94, \quad \mathrm{BPP}=0.98)$, Lanceocercata $\quad(\mathrm{MLB}=97$, $\mathrm{BPP}=0.98), \quad$ Lonchodinae $\quad(\mathrm{BPP}=0.97), \quad$ Pharnaciini $(\mathrm{MLB}=75, \mathrm{BPP}=0.99)$, Phylliinae $(\mathrm{MLB}=100, \mathrm{BPP}=0.99)$ and Stephanacridini $(\mathrm{MLB}=98, \mathrm{BPP}=0.99)$. Clades less well supported, but also monophyletic in accordance with previous studies [24, 30-32] are Heteropteryginae $(\mathrm{BPP}=0.93)$, Necrosciinae $(\mathrm{BPP}=0.94)$, Pseudophasmatinae $(\mathrm{BPP}=0.91)$ and Diapheromerinae $(\mathrm{BPP}=0.63)$. Some further, previously unrecognized groupings that receive good support comprise a Malagasy lineage Achrioptera+ Anisacanthidae + Damasippoididae $(\mathrm{MLB}=61, \mathrm{BPP}=0.98)$ and an African clade of paraphyletic Gratidiini (Gratidia, Zehntneria $)+$ Phalces (Bacillinae $)(\mathrm{MLB}=100, \mathrm{BPP}=0.98)$. Bacillidae (Antongilia, Phalces, Xylica) and Pachymorphinae (Clonaria, Gratidia, Pachymorpha, Sceptrophasma, Spinotectarchus, Zehntneria) were recovered as polyphyletic.

Within Lanceocercata we corroborated earlier findings that Platycraninae is monophyletic $(\mathrm{MLB}=100, \mathrm{BPP}=1)$

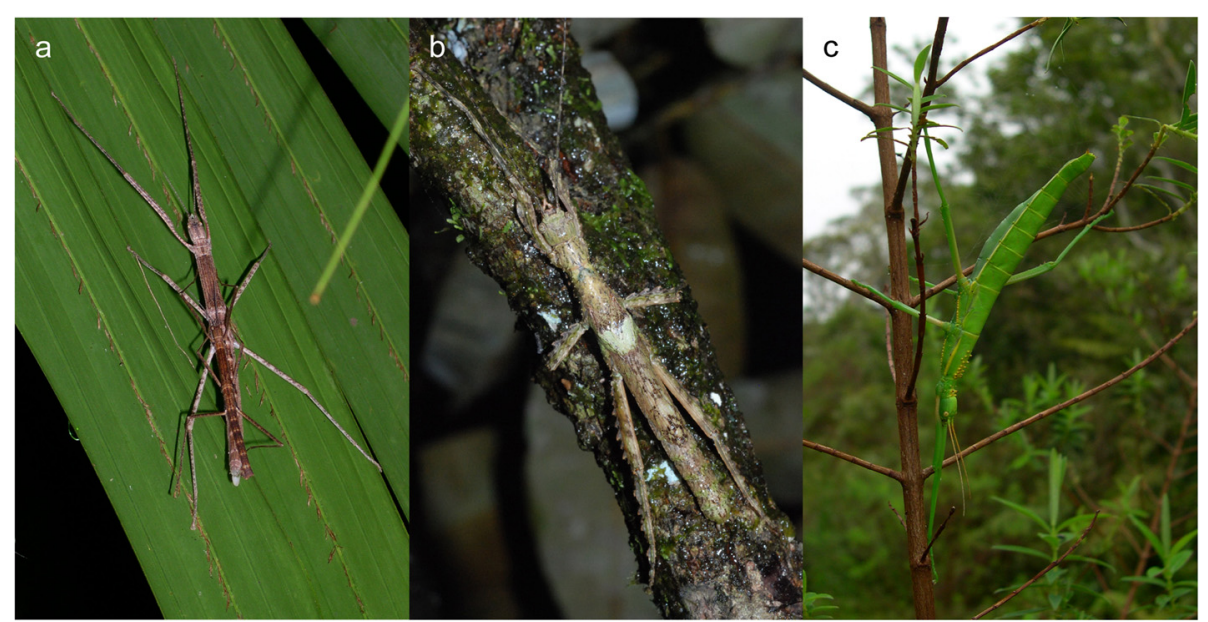

Fig. 1 Photos of Mascarene stick insects. a Couple of Apterograeffea reunionensis (Platycraninae) from Réunion. b Male of Epicharmus marchali (Xeroderinae) from Mauritius. c Female of Rhaphiderus spiniger (Tropidoderinae) from Réunion 


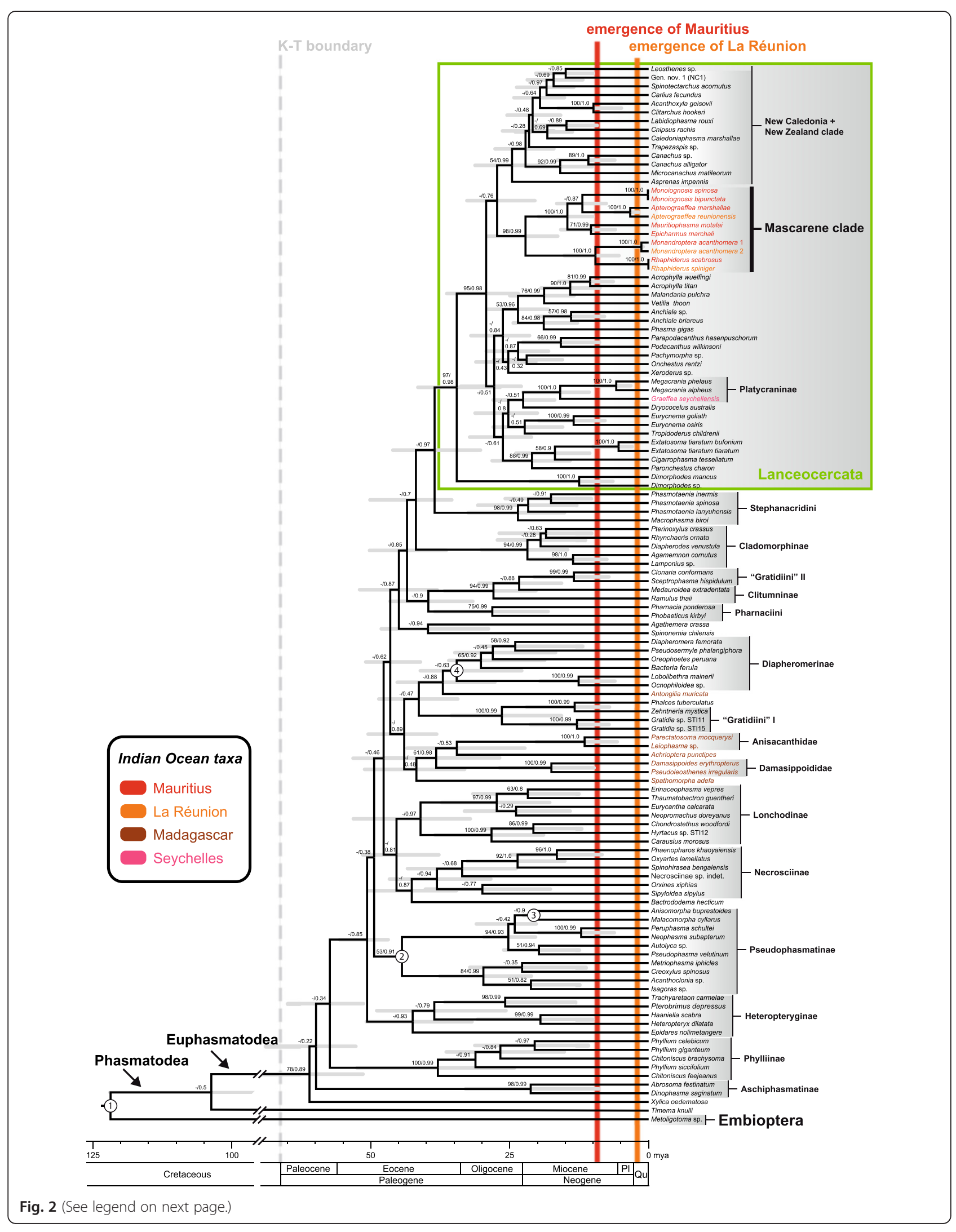


(See figure on previous page.)

Fig. 2 Chronogram of the sampled stick insect specimens with taxa distributed across the Indian Ocean highlighted in tones of red. Numbers at nodes indicate bootstrap values (left) and clade posterior probabilities (right); grey bars show $95 \%$ highest probability density. Circled numbers refer to fossil calibration points: (1) Renphasma [56], (2) Eophasma [61], (3) fossil Malacomorpha [63], (4) fossil Clonistria [63]. PI Pliocene, Qu Quaternary

including Graeffea seychellensis, but excluding Apterograef$f e a$, and a clade comprising all taxa from New Caledonia and New Zealand $(\mathrm{MLB}=54, \mathrm{BPP}=0.98)[20,24,33]$. All individuals sampled from the Mascarene archipelago (9 species, 6 genera) form one strongly supported clade $(\mathrm{MLB}=98, \mathrm{BPP}=0.99)$ among Lanceocercata. Within the Mascarene lineage, all genera are well supported $(\mathrm{MLB}=100, \mathrm{BPP}=1)$ with a clade of Monandroptera + Rhaphiderus $(\mathrm{MLB}=100, \mathrm{BPP}=1)$ being sister to the remaining Mascarene taxa $(\mathrm{MLB}=100, \mathrm{BPP}=1)$. Mauritiophasma and Epicharmus are sister taxa $(\mathrm{MLB}=71$, $\mathrm{BPP}=0.99)$ as well as Apterograeffea and Monoiognosis $(\mathrm{BPP}=0.87)$.

The Mascarene clade diverged from the remaining Lanceocercata approximately 27.15 mya, between 20.16 and 33.07 mya, and started diversifying around 22.03 mya ago, between 15.99 and 29.39 mya. The overall divergence time estimates indicate a recent diversification of Euphasmatodea beginning 61.26 mya (51.04-75.43 mya). The split between Timema and Euphasmatodea occurred 103 mya (85.52-122.12 mya).

\section{Discussion}

\section{Mascarene stick insect phylogeny}

Recent studies have revealed that convergently evolved features have often been the basis of classification [24, 34]. Molecular studies provide a breakthrough in the investigation of these radiations since they avoid the use of circularly interpreted characters. Our molecular phylogeny did not support the traditional classification of Mascarene stick insects, which predicted that the respective fauna consists of five unrelated lineages, and, consequently, implied the occurrence of multiple colonisation events leading to the present-day phasmatodean community in the archipelago [22]. Instead we recovered a single origin of all Mascarene stick insects, forming a strongly supported lineage deeply nested within the highly diverse Australasian Lanceocercata (Fig. 2). All Mascarene genera we sampled here (6) and the majority of species (7) are found on Mauritius, which is generally considered to be the oldest island in the archipelago, its volcanic emergence dated 7.8 mya [5]. Three genera, Apterograeffea, Monandroptera, and Rhaphiderus, also have species on Réunion, which is a much younger island dated at 2.1 mya [5]. The age of Rodrigues has been debated with estimates ranging between 11 mya for the old volcanic ridge and 1.5 mya for the recent emergent part [5], some sources give 15 mya as the oldest date of its emergence $[7,8,14]$. The only reported, endemic stick insect from Rodrigues, Xenomaches incommodus (Butler, 1876), which is an extinct member of the Platycraninae [35], was not available for our analysis.

The Lanceocercata clade has undergone an impressive evolutionary diversification during the past $\sim 40$ million years that led to several adaptive radiations in geographical isolation, e.g., New Caledonia and New Zealand, resulting in several morphologically and behaviourally convergent ecotypes [20, 24, 33]. Therefore, it did not come as a surprise that the discovery of Lanceocercata rendered numerous traditional systematic entities artificial. Lanceocercata comprises species from six subfamilies, Pachymorphinae, Tropidoderinae, Xeroderinae, Phasmatinae, Eurycanthinae, and Platycraninae, none of which is monophyletic. This knowledge is significantly enhanced by our finding of another unexpected adaptive radiation in the Mascarene archipelago, which involves further strikingly convergent ecotypes. For instance, the Mascarene Apterograeffea (Fig. 1a), traditionally viewed as a member of the Platycraninae (coconut stick insects and allies), exhibits the same enlarged genae ('cheeks') necessary to accommodate the massive mandibular muscles necessary for feeding on hardy palm or screw pine (Pandanus) leaves as do the unrelated Australian and Pacific ecotypes, e.g., Graeffea and Megacrania [22]. On Mauritius, Epicharmus (Fig. 1b), traditionally assigned to Xeroderinae, is a stout winged stick insect with lobes on legs and abdomen, which enhance crypsis of this barkdwelling species, is most reminiscent to the unrelated Australian Xeroderus and New Caledonian Leosthenes. The female of Rhaphiderus (Fig. 1c), hitherto assigned to Tropidoderinae, is a wingless leaf-imitating form very similar to the Australian Malandania and Tropidoderus. This remarkable diversity in appearance and ecology prompted taxonomists to assume the Mascarene species to be unrelated to each other, especially in regard of the young age of Mauritius, and to incorrectly place them in different subfamilies.

\section{Origins of the Mascarene fauna}

Usually, islands are colonised from the nearest land source, and not surprisingly the Mascarene biota shows close affinities to Madagascar, which is approximately $700 \mathrm{~km}$ away. Terrestrial vertebrates like giant tortoises [36], Phelsuma day geckos [10] and slit-eared skinks [11] and also recently studied invertebrates such as carnivorous land-snails [12] and the golden orb spider Nephila [13] are few examples among many others $[7,8,14]$. We, in contrast, found no close relationships between any Malagasy 
lineage of stick insects and those of the Mascarene archipelago and, based on a more restricted sampling, already demonstrated the Mascarene Tropidoderinae, Monandroptera and Rhaphiderus, are deeply nested within the Australasian Lanceocercata [20, 24]. Indo-Pacific ancestors of Mascarene lineages have been revealed before. The most famous example might be the extinct dodo (Raphus) on Mauritius and the solitaire (Pezophaps) from Rodrigues, which form sister taxa with close relatives in Southeast Asia $[15,16]$. Nactus geckos and skinks of the genus Leiolopisma are further examples showing Australasian origins [19]. The arrival of Leilopisma skinks in the Mascarenes requires a spectacular transmarine dispersal between $5600 \mathrm{~km}$ from West Australia or more than $7000 \mathrm{~km}$ from a more tropical region such as New Guinea. A similar route must have been taken by the ancestral Mascarene stick insect. An east-west directed ocean stream towards Madagascar, the South Equatorial current, which was already existent during the Oligocene and Miocene, is most likely responsible for these kinds of long-distance transoceanic passages $[37,38]$. It has recently been demonstrated that the hard-shelled, seed-like eggs of certain phasmatodeans can survive a significant amount of time (several months) under marine conditions, e.g., floating on seawater [39]. Eggs of Mascarene stick insects are often glued to twigs and other plant substrate [23], which would further facilitate above-water dispersal. It is noteworthy that the remarkable transoceanic journey via east-west dispersal across the Indian Ocean occurred twice within Lanceocercata and is not restricted to the Mascarene clade alone. Graeffea seychellensis, a member of the true coconut stick insects (Platycraninae) (cf. Fig. 2) that are distributed in Australia and throughout the Southwest Pacific, reached and colonised the Granitic Seychelles. Ocean currents are also likely responsible for repeated dispersals from Mauritius towards Réunion. Both islands have never been connected by land and are separated by $164 \mathrm{~km}$ from each other [8], nevertheless members of three Mascarene genera, Apterograeffea, Monandroptera, and Rhaphiderus, colonised Réunion since its emergence. Island colonisations are contingent events. Whereas colonisations of New Caledonia and New Zealand led to flourishing stick insect radiations [20, 24], the Pacific Galápagos Islands and the Hawaiian archipelago are devoid of any phasmatodeans. Peculiarly, Madagascar was never successfully colonised by Lanceocercata $[20,40]$ either from Australia or the Mascarenes, despite being separated from the latter, viz. Réunion, by only $665 \mathrm{~km}$ of ocean [8], far less than the 5600-7000 km that separate Australia from the Mascarenes, and it forms a significantly larger target area than the Mascarene Islands or Seychelles. However, the size and structure of the ancient island community of the Mascarene plateau, which might had much larger landmasses than today, especially during sea-level lowstands [8, 17], remains speculative. We cannot preclude that Lanceocercata might have actually arrived on Madagascar, but was not able to persist and diversify because the Malagasy lineage of stick insects, which colonised the island earlier (between 38 and 51 mya), already underwent a flourishing radiation and largely reduced ecological opportunities for any newcomer.

\section{Timing the Mascarene colonisation}

Most surprisingly, we obtained a time estimate for the origin of the Mascarene clade that significantly exceeds the geological ages of the extant emerged islands. At 22.03 mya (15.99-29.39 mya) the Mascarene phasmid lineage began to radiate long before Mauritius is supposed to have emerged (8-10 mya) [5, 8]. This result is largely contrasted by the recent accumulation of molecular phylogenetic studies favouring recent arrival and diversification of terrestrial colonisers, e.g., 3.5-5.1 mya for Phelsuma day geckos [10], 3 mya for slit-eared skinks [11], 1.9-7.4 mya for hermit spiders and 0.8 mya for Nephila spiders [13]. Austin and Arnold [19] recovered a divergence time of 17 mya for Mascarene Leiolopisma skinks, however this refers to the stem divergence time separating the Mascarene skinks from their most closely related Australian relatives. This might represent an over-estimate, since the age of the branching between the island lineage and the outside relative (the continental sister group) marks the upper time limit of colonisation, because the closest outside relative might be unsampled or extinct [3]. Consequently, the colonisation event could have occurred significantly later. On the other hand, the age of the most recent common ancestor of a multi-species lineage of island organisms marks the lower limit, because it is possible that the ancestral species colonised the island long before the historically known taxa began to diversify (= crown divergence time) [3]. The crown divergence time of Leiolopisma skinks, when speciation on Mauritius began, is dated to 3.4 mya [19], thus being concordant with the island's geological age. A similar pattern is observed in certain flowering plants (Laurales: Monimiaceae) with a stem divergence time of 31.55 mya between Monimia (Réunion) and its sister Palmeria (Australia) and a crown divergence time of Monimia of 1.34 mya [18]. In contrast, the crown divergence time of the Mascarene palm genus Hyophorbe is observed to lie between 12 and 14 mya, albeit with a lower $95 \%$ confidence interval boundary falling within the assumed age of the Mascarene Islands [41], unlike our results.

We used a twofold conservative approach to date the Mascarene phasmid lineage, since our analysis is based on fossil calibrations, and any given fossil indicates the minimum time of the taxon in question, and we refer to 
the crown divergence time, a potential under-estimate. Taking this into consideration, it is possible that the Mascarene clade (and the whole phasmatodean tree) is even older than suggested by our analysis. We calibrated the split between Phasmatodea and Embioptera at 122 mya, whereas recent studies based on transcriptomic data inferred much older estimates of 164 mya [29] and even at 250 mya [42] and (based on a combination of nuclear and mitochondrial markers) at 260 mya [43] for the same node. In a previous less conservative approach based on published mitochondrial DNA (mtDNA) rates only, we estimated the stem divergence time of 39.5 mya for the Mascarene members of Tropidoderinae alone [20]. However, molecular clock analyses based on mitochondrial genes can overestimate divergence times [44]. For instance the proposed ancient split $(\sim 10$ mya) between the two Galápagos iguanas based on mtDNA suggested speciation on now-sunken islands of the archipelago [2], which was recently challenged by a study using protein-coding nuclear genes and arriving at a much younger divergence ( 4.5 mya) on currently subaerial islands [45].

Confidence in our time estimates as proposed here gains further support by the dates we obtained for the inter-island splits of the three phasmid genera that have members on both Mauritius and Réunion. The split between the two species of Apterograeffea is 3.45 mya (1.41-6.02 mya), and 0.05 mya (0.01-0.11 mya) lie between Rhaphiderus scabrosus and $R$. spiniger. The split between the two Monandroptera acanthomera specimens, which are considered to represent one single species despite their greater genetic distance, is dated 1.4 mya (0.5-2.51 mya). These dates are consistent with dispersal from Mauritius to Réunion following formation of the latter at least 2.1 mya.

A potential explanation for the discrepancy between the young age of Mauritius and the greater age of the respective lineage of stick insects is provided by historical tectonic and volcanic events in the western Indian Ocean. The Mascarene archipelago is considered to be the product of an age-progressive trend of north-to-south volcanic activity, the Réunion hot spot chain, with a northward increase in age of volcanic activity [5]. It is assumed that many parts of the Réunion hot spot chain were above sea level over the last 65 million years at the time of their formation (Fig. 3) and that these islands would have been temporarily available as stepping-stones for lineages dispersing between India and Madagascar [12, 17]. The next major islands that emerged prior to the rise of Mauritius were Saint Brandon (Cargados-Carajos), $385 \mathrm{~km}$ north-east of Mauritius, dated 31 mya, and Nazareth Bank, which is nearly contiguous with St. Brandon bank at its northern margin, dated at 35 mya [8]. Based on our conservative divergence time estimates we reject the possibility of an ancestral Mascarene phasmid arriving in Mauritius and instead propose the scenario of a colonisation of either Nazareth Bank or St. Brandon with subsequent radiation and dispersal towards the much younger Mauritius. Smaller uplifts between St. Brandon and Mauritius, e.g., Baissac Bank and Soudan Bank (Fig. 3), might have further facilitated spread of terrestrial faunal elements. This steppingstone route was already assumed for the extinct dodo on Mauritius and its sister, the solitaire, on Rodrigues, which exhibit an equally deep divergence time between 23-25 mya $[15,16]$, and also for two sister taxa of land-snails [12]. With only two taxa involved, the alternative, albeit less parsimonious hypothesis that they diverged on a distant landmass and colonised the islands independently, has to be considered [2]. However, the more diverse radiation of stick insects with a distant Australasian origin makes this scenario very unlikely. It is likewise implausible to assume multiple colonisations from still existent landmasses in the Indian Ocean, such as Madagascar, that requires the assumption that each coloniser's sister taxon went extinct on this landmass after the colonisation event. Another potential source of colonisation could be Rodrigues whose upper age estimate (15 mya) nearly overlaps with our lower estimate of the Mascarene phasmid clade (16 mya). Given that our estimate, if anything, is an under-estimate, the timespan difference between the origin of the Mascarene clade and the emergence of Rodrigues is probably much larger. Furthermore, past studies have shown that Rodrigues is rather a sink than a source for colonisers with not a single organismic lineage of Rodrigues having colonised any other island in the region [14]. Thus, the possibility of Rodrigues as a source for the Mascarene stick insects appears highly unlikely. A further alternative hypothesis in accordance with our data would be that Mauritius is much older than previously thought. A recent study suggests the presence of a Precambrian microcontinent in the Indian Ocean, now covered by younger magmatic deposits that separated from Madagascar 61-83.5 mya and fragmented into a ribbon-like configuration that also comprises Mauritius [6]. However, this conclusion does not necessarily mean that all of these continental fragments, including Mauritius, were above sea level before the more recent volcanic uplift. Nevertheless, exposed lavas in the Mascarenes are often the result of recent volcanic reactivation and might impede the detection of the true age of the underlying geology [7].

Consequently, we favour the assumption that submerged islands such as St. Brandon have existed continuously above sea level since its formation until the emergence of Mauritius, viz. over a period of more than 20 million years.

\section{Speciation in the Mascarene archipelago}

We found limited evidence for speciation of stick insects on Mauritius. The dates for the inter-generic splits of 


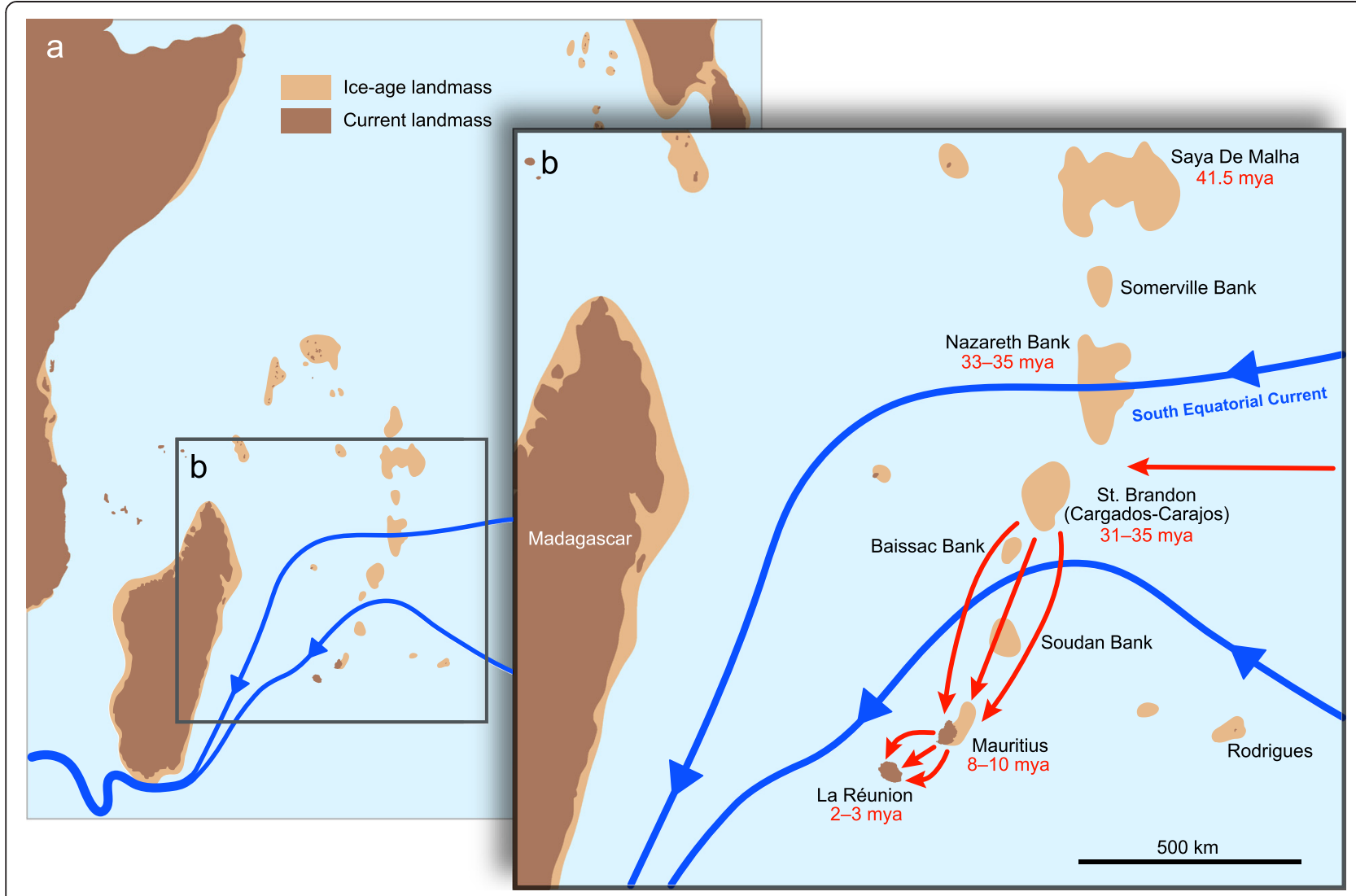

Fig. 3 Dispersal scenario of Mascarene stick insects superimposed on a map of the Indian Ocean. a Current map of the Indian Ocean. $\mathbf{b}$ Enlarged view of Mascarene plateau. Red arrows indicate postulated colonisation events: The ancestral Mascarene stick insect arrived on currently submerged islands located to the North of Mauritius followed by a radiation and at least three (maximal six) independent dispersals to Mauritius and another three dispersals to Réunion, most likely facilitated by ocean currents (blue lines, after [37])

Mascarene phasmatodeans predate the island's age again. It is generally assumed that a minimum island size exists below which speciation is rather unlikely due to the lack of opportunities for geographical isolation and niche partitioning [46]. Small islands, like those forming the current Mascarene archipelago, lack speciation in some organismic lineages, as recently observed for Tetragnatha spiders [47], because these islands do not allow for sufficient geographical isolation (allopatric speciation) and provide fewer ecological opportunities, e.g., less niche space than large islands, that would more readily allow diversification due to ecological specialisation (sympatric speciation). Yet, the weevil genus Cratopus underwent a quite impressive radiation in the archipelago leading to more than 80 species [7]. Before severe habitat destruction since the $17^{\text {th }}$ century, Mauritius was homogenously covered by semi-dry palm forest and moist tropical rain forest [8], but the much younger Mauritius might have been ecologically more diverse. The current landscape of distantly spaced small islands in the Mascarene archipelago was probably preceded by a period of larger islands that more readily allowed for speciation. Therefore, it appears plausible that at least some speciation took place on (intra-island) or between (inter-island) these former, now submerged northern landmasses, which apparently were much larger than Mauritius, e.g., St. Brandon, Nazareth Bank (Fig. 3), followed by repeated colonisations, 3-6 times, of Mauritius. In fact, multiple dispersals towards Mauritius are not unlikely since stick insects already colonised Réunion at least three times during the past 2 million years alone. Allopatry might have played an important role in regard of the deeper nodes of the Mascarene stick insects and was most likely crucial for more recent speciation events. With the exception of Monoiognosis, which has only very recently diverged into two species on Mauritius, further intra-generic splits occurred only in geographical isolation after colonisation of Réunion. Similar patterns are observed in the Mascarene radiations of giant tortoises [36] and geckos [10], in which allopatric inter-island speciation as well as sympatric intraisland speciation events are reported.

\section{Conclusion}

In summary, the results of our phylogenetic analysis and divergence time estimates strongly suggest that 
the Mascarene stick insects are older than the landmass they currently inhabit. We conclude that the ancestral Mascarene stick insect colonised former, now sunken islands, most probably located to the north of Mauritius. It has been suggested before that subsided seamounts throughout the Indian Ocean, when fully above water, could have served as stepping-stones between India and the Mascarenes and would have reduced the distance for oceanic dispersal [12, 14-18, 41]. However, fossil evidence for a subaerial past has so far only been provided for the Paleocene islands in the Ninetyeast Ridge [48]. Concordant with previous conclusions $[8,15,41]$, our results imply that ancient islands must have existed permanently above sea level throughout the Oligocene and Miocene. We expect future phylogeographic investigations in the Mascarene archipelago, which still remains a comparatively uncharted study system, to reveal further deep divergence times in support of our observations and explanations.

\section{Methods}

\section{DNA extraction and phylogenetic analysis}

We extracted and sequenced DNA from 38 stick insect specimens and combined these data with 83 previously sequenced taxa, which represent all major lineages currently recognised in Phasmatodea (see Additional file 1: Table S1 for detailed information) [24, 31]. We focussed on a particularly dense sampling of stick insects from the landmasses of the Indian Ocean. We included nearly all known genera and species from Mauritius and Réunion, which represent members of different taxonomic units, e.g., Apterograeffea (Platycraninae), Epicharmus (Xeroderinae), Mauritiophasma (Phasmatinae), Monandroptera and Rhaphiderus (Tropidoderinae), and Monoiognosis (incertae sedis). We were unable to obtain a sample of Heterophasma multispinosum Cliquennois and Brock, 2004 from Réunion, another genus currently placed in Tropidoderinae, and of the extinct Xenomaches incommodus from Rodrigues, currently assigned to Platycraninae.

We amplified regions of the mitochondrial cytochrome c oxidase subunit I (COI) and II (COII) genes and the nuclear Histone subunit $3(\mathrm{H} 3)$ and ribosomal large subunit RNA gene (28S) using methods described previously [24]. Chromatograms were edited in Geneious 7.1.5 (http://www.geneious.com) [49]. DNA sequences were aligned using Muscle [50] as implemented in Geneious v7.1.5 (http://www.geneious.com [49]). We used GBLOCKS [51] to identify regions in the alignment with a large number of contiguous conserved positions of a minimum length. We used the GBLOCKS server and implemented the "options for a less stringent selection". The data were partitioned into four character sets; mitochondrial $1^{\text {st }}$ and $2^{\text {nd }}$ codon positions, mitochondrial $3^{\text {rd }}$ codon positions, $\mathrm{H} 3$ gene and $28 \mathrm{~S}$ gene. Model selection was performed separately on each partition using JModelTest v.2.1.3 [52]. We used the AIC to select from a set of 88 models with base frequencies estimated. Likelihoods were calculated on a BioNJ tree that was fixed across models. Phylogenetic analyses were performed in maximum likelihood and Bayesian frameworks using Garli v2.0 [53] and BEAST 1.7.4 [54] respectively. For the Garli analyses we performed 100 bootstrap replicates with 20 random addition replicates per bootstrap. A partitioned model was employed with parameter estimates from JmodelTest. For the Bayesian analyses we used a log Normal distributed relaxed clock model [55] under a Yule speciation prior (10) with the following exponential priors for the nucleotide substitution model parameters; relative substitution rates $=100$, relative rate matrix parameters $=1.0$, alpha shape parameter $=0.5$, uncorrelated log Normal mean $=$ 0.5 , uncorrelated $\log$ Normal standard deviation $=0.5$. For the proportion of invariable sites a uniform distribution bounded by 0 and 1.0 was used. The analyses were run for 60 million generations, sampling every 1000 generations.

\section{Fossil calibrations}

To calibrate the phylogeny we used four fossils that we were able to assign to specific nodes on the tree. The first calibration was obtained from the Yixian Formation in Liaoning, China based on an adult male specimen, Renphasma sinica [56]. This is the oldest fossil that can be clearly identified as a true phasmatodean [57]. Males of Phasmatodea possess a sclerotised hook on the venter of abdominal segment 10, the vomer, between a pair of unsegmented cerci, which are interpreted as unambiguous apomorphic characters for Phasmatodea [58], both exhibited by Renphasma [56]. The Yixian Formation dates from at least 122.1 mya [59]. We calibrated the root of the tree that separates the Embioptera from the Phasmatodea with an exponential prior with mean of 1.0 and offset at 122 mya. This represents a conservative approach to dating because we have calibrated the deeper Embioptera/Phasmatodea split, rather than shallower crown group radiations. The effect of this conservative approach is to yield more recent divergence times than applying crown-group calibrations. Further calibrations were provided based on fossil eggs. Eggs of stick insects are hard-shelled and richly sculptured with speciesspecific traits that are considered to be of major taxonomic importance for the order $[32,60]$. The second calibration was from Clark Sellick [61], who described fossil eggs from the Eocene Clarno Formation Nut Beds of Oregon. These species can confidently be assigned to the Pseudophasmatinae subgroup Anisomorphini because their eggs bear a conspicuous negative opercular angle [61], which represents a derived state among phasmatodean eggs. The Clarno Formation has been dated to 44 mya [62]. We calibrated the basal node of the Pseudophasmatinae with an exponential prior with mean 
of 1.0 and offset at 44 mya. The third and fourth calibrations were taken from Poinar [63] who described two fossil eggs from Clonistria and Malacomorpha from Dominican amber on Hispaniola. We used the Malacomorpha fossil to date the divergence of this genus from its sister taxon Anisomorpha. Eggs of some Malacomorpha species, e.g., M. cyllarus (Westwood, 1859), have a very specific rugose capsule with raised net-like protuberances [64]. We used the Clonistria fossil to date the basal divergence of the Diapheromerinae. Clonistria eggs can be determined by their vesicular, open capitulum broadly covering the operculum, which is not present in the ground pattern of Diapheromerinae (absent in Ocnophiloidea and Lobolibethra) [60,63]. Both genera, Clonistria and Malacomorpha have numerous extant members on Hispaniola [63, 64]. Dating of Dominican amber is controversial, with the youngest proposed age of 15-20 mya based on foraminifera and the oldest as 30-45 mya based on coccoliths $[65,66]$, with the specific amber containing the fossil phasmatodeans from La Buscara mine being dated between 20 and 40 million years [63]. In order to be conservative we used an exponential prior with mean of 1.0 and offset at 20 and 40 mya respectively.

\section{Additional file}

Additional file 1: Table S1. List of species included in this study with Genbank accession numbers for each gene. Cells with a dash indicate missing data. Taxa in alphabetical order with subfamily assignment following [24] with amendments from [22, 23, 31]. Mascarene taxa in bold. (PDF $167 \mathrm{~kb}$ )

\section{Competing interests}

The authors declare that they have no competing interests.

\section{Authors' contributions}

SB and TRB conceived the project and designed research. NC collected material. TRB analysed the molecular data. SB, NC and TRB interpreted the results. SB and TRB wrote the paper. NC contributed to manuscript editing. All authors have approved of the final version of the manuscript.

\section{Acknowledgements \\ This work was supported by the German Science Foundation (DFG grant BR 2930/2-1 to SB). TRB was part funded by the Allan Wilson Centre and the University of Auckland. We thank Sylvain Hugel (Strasbourg, France), Bruno Kneubühler (Lucerne, Switzerland) and Kristien Rabaey (Veurne, Belgium) for providing stick insect samples. Bernd Baumgart (Göttingen, Germany) provided technical support. DNA sequences were collected by Anna Ramon-Laca, Julia Allwood, and Ruby Cheah (Auckland, New Zealand). This work was conducted in compliance with the CBD (Convention on Biological Diversity) and under CBD's Access and Benefit-Sharing (ABS) system.}

\section{Author details}

${ }^{1}$ Johann-Friedrich-Blumenbach-Institute of Zoology and Anthropology, Georg-August-University Göttingen, Berliner Str. 28, 37073 Göttingen, Germany. ${ }^{2}$ Collège français, Lot 02 F 15 Tomboarivo, B.P. 141, 110, Antsirabe, Madagascar. ${ }^{3}$ Landcare Research, Private Bag 92170, Auckland, New Zealand. ${ }^{4}$ School of Biological Sciences, The University of Auckland, Private Bag 92019, Auckland, New Zealand. ${ }^{5}$ Allan Wilson Centre, Auckland, New Zealand.

Received: 22 June 2015 Accepted: 3 September 2015

Published online: 16 September 2015

\section{References}

1. Myers N, Mittermeier RA, Mittermeier CG, da Fonseca GAB, Kent J. Biodiversity hotspots for conservation priorities. Nature. 2000;403:853-8.

2. Rassmann K. Evolutionary age of the Galápagos Iguanas predates the age of the present Galápagos Islands. Mol Phylogenet Evol. 1997;7:158-72.

3. Price JP, Clague DA. How old is the Hawaiian biota? Geology and phylogeny suggest recent divergence. Proc R Soc Lond B. 2002;269:2429-35.

4. Sheth HC, Mahoney JJ, Baxter AN. Geochemistry of lavas from Mauritius, Indian Ocean: mantle sources and petrogenesis. Int Geol Rev. 2003:45:780-97.

5. Duncan RA. Mascarene islands, geology. In: Gillespie RG, Clague DA, editors Encyclopedia of islands. Berkeley: University of California Press; 2009. p. 620-2.

6. Torsvik TH, Amundsen H, Hartz EH, Corfu F, Kusznir N, Gaina C, et al. A Precambrian microcontinent in the Indian Ocean. Nat Geosci. 2013;6:2023-7.

7. Thébaud C, Warren BH, Strasberg D, Cheke A. Mascarene islands, biology. In: Gillespie RG, Clague DA, editors. Encyclopedia of islands. Berkeley: University of California Press; 2009. p. 612-9.

8. Cheke A, Hume J. Lost land of the Dodo. New Haven: Yale University Press; 2007.

9. Rosauer D, Laffan SW, Crisp MD, Donnellan SC, Cook LG. Phylogenetic endemism: a new approach for identifying geographical concentrations of evolutionary history. Mol Ecol. 2009;18:4061-72.

10. Austin JJ, Arnold EN, Jones CG. Reconstructing an island radiation using ancient and recent DNA: the extinct and living day geckos (Phelsuma) of the Mascarene islands. Mol Phylogenet Evol. 2004;31:109-22.

11. Austin JJ, Arnold EN, Jones CG. Interrelationships and history of the slit-eared skinks (Gongylomorphus, Scincidae) of the Mascarene islands, based on mitochondrial DNA and nuclear gene sequences. Zootaxa. 2009;2153:55-68.

12. Rowson B, Tattersfield P, Symondson WOC. Phylogeny and biogeography of tropical carnivorous land-snails (Pulmonata: Streptaxoidea) with particular reference to East Africa and the Indian Ocean. Zool Scripta. 2010;40:85-98.

13. Kuntner M, Agnarsson I. Phylogeography of a successful aerial disperser: the golden orb spider Nephila on Indian Ocean islands. BMC Evol Biol. 2011;11:119.

14. Agnarsson I, Kuntner M. The Generation of a Biodiversity Hotspot: Biogeography and Phylogeography of the Western Indian Ocean Islands. In: Anamthawat-Jónsson K, editor. Current Topics in Phylogenetics and Phylogeography of Terrestrial and Aquatic Systems. InTech. 2012. p. 33-82.

15. Shapiro B, Sibthorpe D, Rambaut A, Austin J, Wragg GM, Bininda-Emonds ORP, et al. Flight of the dodo. Science. 2002;295:1683.

16. Pereira SL, Johnson KP, Clayton DH, Baker AJ. Mitochondrial and nuclear DNA sequences support a Cretaceous origin of Columbiformes and a dispersal-driven radiation in the Paleogene. Syst Biol. 2007;56:656-72.

17. Warren BH, Strasberg D, Bruggeman JH, Prys-Jones RP, Thébaud C. Why does the biota of the Madagascar region have such a strong Asiatic flavour? Cladistics. 2010;26:526-38.

18. Renner SS, Strijk JS, Strasberg D, Thébaud C. Biogeography of the Monimiaceae (Laurales): a role for East Gondwana and long-distance dispersal, but not West Gondwana. J Biogeogr. 2010;37:1227-38.

19. Austin JJ, Arnold EN. Using ancient and recent DNA to explore relationships of extinct and endangered Leiolopisma skinks (Reptilia: Scincidae) in the Mascarene islands. Mol Phylogenet Evol. 2006:39:503-11.

20. Buckley TR, Attanayake D, Nylander JAA, Bradler S. The phylogenetic placement and biogeographical origins of the New Zealand stick insects. Sys Ent. 2010;35:207-22.

21. Maginnis TL. Leg regeneration stunts wing growth and hinders flight performance in a stick insect (Sipyloidea sipylus). Proc R Soc Lond B. 2006:273:1811-14.

22. Cliquennois N, Brock PD. Apterograeffea, un nouveau genre de Phasme de la Réunion et de l'île Ronde (Phasmatodea, Platycraninae). Bull Soc Ent France. 2002;107:387-95.

23. Cliquennois N, Brock PD. Phasmids of Mauritius: Mauritiophasma n. gen. Monoiognosis n. gen., Epicharmus Stål 1875 and discussion on their remarkable eggs (Phasmatodea). J Orth Res. 2004;13:1-13.

24. Buckley TR, Attanayake D, Bradler S. Extreme convergence in stick insect evolution: phylogenetic placement of the Lord Howe island tree lobster Proc R Soc Lond B. 2009:276:1055-62.

25. Whiting MF, Bradler S, Maxwell T. Loss and recovery of wings in stick insects. Nature. 2003:421:264-7.

26. Ishiwata K, Sasaki G, Ogawa J, Miyata T, Su Z-H. Phylogenetic relationships among insect orders based on three nuclear protein-coding gene sequences. Mol Phylogenet Evol. 2011;58:169-80. 
27. Friedemann K, Wipfler B, Bradler S, Beutel RG. On the head morphology of Phyllium and the phylogenetic relationships of Phasmatodea (Insecta). Acta Zool. 2012;93:184-99.

28. Letsch $H$, Simon S. Insect phylogenomics: new insights on the relationships of lower neopteran orders (Polyneoptera). Sys Ent. 2013;38:783-93.

29. Misof B, Liu S, Meusemann K, Peters RS, Donath A, Mayer C, et al. Phylogenomics resolves the timing and pattern of insect evolution. Science. 2014;346:763-7.

30. Tomita S, Yukuhiro K, Komoto N. The mitochondrial genome of a stick insect Extatosoma tiaratum (Phasmatodea) and the phylogeny of polyneopteran insects. J Ins Biotech Sericol. 2011;80:79-88.

31. Bradler S, Robertson JA, Whiting MF. A molecular phylogeny of Phasmatodea with emphasis on Necrosciinae, the most species-rich subfamily of stick insects. Syst Ent. 2014;39:205-22.

32. Goldberg J, Bresseel J, Constant J, Kneubühler B, Leubner F, Michalik P, et al. Extreme convergence in egg-laying strategy across insect orders. Sci Rep. 2015;5:7825.

33. Dunning LT, Thomson G, Dennis AB, Sinclair BJ, Newcomb RD, Buckley TR. Positive selection in glycolysis among Australasian stick insects. BMC Evol Biol. 2013;13:215.

34. Bossuyt F, Milinkovitch MC. Convergent adaptive radiations in Madagascan and Asian ranid frogs reveal covariation between larval and adult traits. Proc Natl Acad Sci U S A. 2000:97:6585-90.

35. Cliquennois N. "Vivant, était vert avec des antennes rouges": extinction de Xenomaches incommodus, phasme endémique de l'île Rodrigues (Phasmatodea). Bull Soc Ent France. 2007;112:375-6.

36. Austin JJ, Arnold EN. Ancient mitochondrial DNA and morphology elucidate an extinct island radiation of Indian Ocean giant tortoises (Cylindraspis). Proc R Soc Lond B. 2001;268:2515-23.

37. Stramma L, Lutjeharms JRE. The flow field of the subtropical gyre of the South Indian Ocean. J Geophys Res. 1997;102:5513-30.

38. Ali JR, Huber M. Mammalian biodiversity on Madagascar controlled by ocean currents. Nature. 2010;463:653-6.

39. Kobayashi S, Usui R, Nomoto K, Ushirokita M, Denda T, Izawa M. Does egg dispersal occur via the ocean in the stick insect genus Megacrania (Phasmida: Phasmatidae)? Ecol Res. 2014:29:1025-32.

40. Cliquennois N. Aperçu général de la diversité des phasmes de Madagascar (Insecta, Phasmatodea). Le bulletin d'Arthropoda. 2007:32:3-16.

41. Cuenca A, Asmussen-Lange CB, Borchsenius F. A dated phylogeny of the palm tribe Chamaedoreeae supports Eocene dispersal between Africa, North and South America. Mol Phylogenet Evol. 2008;46:760-75.

42. Tong KJ, Duchêne S, Ho SYW, Lo N. Comment on "Phylogenomics resolves the timing and pattern of insect evolution". Science. 2015;349:487-b.

43. Rainford JL, Hofreiter M, Nicholson DB, Mayhew PJ. Phylogenetic distribution of extant richness suggests metamorphosis is a key innovation driving diversification in insects. PLoS One. 2014;10, e109085.

44. Near TJ, Eytan Rl, Dornburg A, Kuhn KL, Moore JA, Davis MP, et al. Resolution of ray-finned fish phylogeny and timing of diversification. Proc Natl Acad Sci U S A. 2012;109:13698-703.

45. MacLeod A, Rodríguez A, Vences M, Orozco-terWengel P, García C, Trillmich F, et al. Hybridization masks speciation in the evolutionary history of the Galápagos marine iguana. Proc R Soc London B. 2015;282:20150425.

46. Losos JB, Ricklefs RE. Adaptation and diversification on islands. Nature. 2009:457:830-6.

47. Casquet J, Bourgeois YXC, Cruaud C, Gavory F, Gillespie RG, Thébaud C. Community assembly on remote islands: a comparison of Hawaiian and Mascarene spiders. J Biogeogr. 2015;42:39-50.

48. Carpenter RJ, Truswell EM, Harris WK. Lauraceae fossils from a Paleocene oceanic island, Ninetyeast Ridge, Indian Ocean: ancient long-distance dispersal? J Biogeogr. 2010;37:1202-13.

49. Kearse M, Moir R, Wilson A, Stones-Havas S, Cheung M, Sturrock S, et al. Geneious Basic: an integrated and extendable desktop software platform for the organization and analysis of sequence data. Bioinformatics. 2012;28:1647-9.

50. Edgar RC. MUSCLE: multiple sequence alignment with high accuracy and high throughput. Nucleic Acids Res. 2004;32:1792-7.

51. Talavera G, Castresana J. Improvement of phylogenies after removing divergent and ambiguously aligned blocks from protein sequence alignments. Syst Biol. 2007;56:564-77.

52. Darriba D, Taboada GL, Doallo R, Posada D. JModelTest 2: more models, new heuristics and parallel computing. Nat Methods. 2012;9:772.
53. Zwickl DJ. Genetic algorithm approaches for the phylogenetic analysis of large biological sequence datasets under the maximum likelihood criterion. Ph.D. dissertation, The University of Texas at Austin; 2006.

54. Drummond AJ, Rambaut A. BEAST: Bayesian evolutionary analysis by sampling trees. BMC Evol Biol. 2007;7:214.

55. Drummond AJ, Ho SYW, Phillips MJ, Rambaut A. Relaxed phylogenetics and dating with confidence. PLoS Biol. 2006;4, e88.

56. Nel A, Delfosse E. A new Chinese Mesozoic stick insect. Act Pal Pol. 2011;56:429-32.

57. Bradler S, Buckley TR. Stick insect on unsafe ground: does a fossil from the early Eocene of France really link Mesozoic taxa with the extant crown group of Phasmatodea? Syst Ent. 2011;36:218-22.

58. Bradler S. The vomer of Timema Scudder, 1895 (Insecta: Phasmatodea) and its significance for phasmatodean phylogeny. Courier Forschungs-Inst Senckenberg. 1999:215:43-7.

59. Chang S-C, Zhang H, Renne PH, Fang Y. High-precision ${ }^{40} \mathrm{Ar} /{ }^{39} \mathrm{Ar}$ age for the Jehol Biota. Palaeogeogr Palaeoclimatol Palaeoecol. 2009;280:94-104.

60. Clark Sellick JT. Descriptive terminology of the phasmid egg capsule, with an extended key to the phasmid genera based on egg structure. Sys Ent. 1997;22:97-122.

61. Clark Sellick JT. Phasmida (stick insect) eggs from the Eocene of Oregon. Palaeontology. 1994;37:913-21.

62. Elliott Jr WS, Manchester SR. Petrified wood of southwestern Oregon: Implications for Cenozoic climate change. Palaeogeogr Palaeoclimatol Palaeoecol. 2014;402:1-11.

63. Poinar GO. A walking stick, Clonistria dominicana n. sp. (Phasmatodea: Diapheromeridae) in Dominican amber. Hist Biol. 2011;23:223-6.

64. Conle OV, Hennemann FH, Perez-Gelabert DE. Studies on neotropical Phasmatodea II: Revision of the genus Malacomorpha Rehn, 1906, with the descriptions of seven new species (Phasmatodea: Pseudophasmatidae: Pseudophasmatinae). Zootaxa. 2008;1748:1-64.

65. Iturralde-Vincent MA, Macphee RDE. Age and paleogeographic origin of Dominican amber. Science. 1996;273:1850-2.

66. Poinar GO, Poinar R. The amber forest. Princeton: Princeton University Press; 1999.

\section{Submit your next manuscript to BioMed Central and take full advantage of:}

- Convenient online submission

- Thorough peer review

- No space constraints or color figure charges

- Immediate publication on acceptance

- Inclusion in PubMed, CAS, Scopus and Google Scholar

- Research which is freely available for redistribution 